\title{
Bonding strength of benuang and duabanga glulams using their barks as phenol formaldehyde-filler
}

\author{
Sari Delviana Marbun ${ }^{1}$, Imam Wahyudi ${ }^{*}$, Jajang Suryana ${ }^{2}$ and Deded Sarip Nawawi ${ }^{2}$
}

\author{
*Correspondence: \\ imyudarw16@yahoo.com \\ ${ }^{2}$ Department of Forest \\ Product, Faculty of Forestry, \\ IPB University, Bogor 16680, \\ Indonesia \\ Full list of author information \\ is available at the end of the \\ article
}

\begin{abstract}
In line with environmental issues and forest sustainability, tree bark of two species from tropical rain forests i.e. benuang (Octomeles sumatrana/BN) and duabanga (Duabanga moluccana/DB) was used as filler for phenol formaldehyde resin (PF-filler). The main objective of the research was to analyze effect of tree barks as PF-filler on bonding strength of $\mathrm{BN}$ and $\mathrm{DB}$ glulams produced. Four glue mixture compositions with ratio $P F$, technical filler, and tree bark filler, respectively are 10: 0: 0 (A); 10: 1.5: 0.5 (B); 10: 1.25: 0.75 (C); and 10: 1: 1 (D) were prepared. Characteristics of tree bark and glue mixtures were also investigated. Glulam parameters i.e. moisture content, density, delamination, bonding strength, wood failure, and formaldehyde emission were determined following JAS 1152. Results showed bonding strength was influenced by wood species and glue mixture composition. The B composition - the lowest ratio of tree bark filler-is the best for BN glulam, while for DB glulam D composition - the highest ratio of tree bark filler-was the best. Generally, tree bark filler improved the bonding strength, however, without bark as PF-filler, the failure occurred on the glue line. Furthermore, DB bark is more potential to be utilized as PF-filler.
\end{abstract}

Keywords: Benuang, Bonding strength, Duabanga, Filler, Glulam, Tree bark

\section{Introduction}

Adhesive plays important role in development of wood industry, especially wood composites [1]. As the products increase, the consumption of adhesive was also increases. Until now, synthetic adhesive including phenol formaldehyde (PF) was used as the main binders. Phenol formaldehyde is non-renewable resin which is widely used for exterior purposes due to its high resistance to humidity [2]. However, environmental issues have triggered many efforts to utilize renewable biomass. Some researchers tried to replace synthetic adhesive with adhesive derived from natural and renewable resources [3, 4]. The others tried to reduce the amount of synthetic adhesive. In this research, tree bark was used as filler for PF (PF-filler) to reduce the utilization of petroleum-based adhesive.

In its application, PF is mixed with filler and/or extender to reduce production cost. Extender is an additives that exhibit some intrinsic adhesive properties, while filler is relatively not [5-7]. Extender is commonly proteinaceous and amylaceous substances, such 
as wheat, cornstarch, tapioca flour, soy flour, and sorghum flour. Filler can be organic or inorganic materials. Inorganic fillers that have been tried to be used for adhesive were calcium carbonate [8], glass particles [9], fumed silica [10], waste marble powder [11], and diatomite powder [12]. Organic fillers generally are biomass waste, such as walnut shell, pinenut shell, ginkgonut shell, coconut shell, periwinkle shell, palm kernel, wood flour, waste rubber, corncob residue, and wood waste ash [5, 6, 9, 13-17]. Furthermore, bark flour, such as southern yellow pine bark [18], walnut, chestnut, fir, and spruce barks $[19,20]$, alder bark [5, 6], beech bark [7], and western red cedar bark [21] are organic filler which are widely used for adhesive. The bark is mainly produced as byproducts in wood industry. Utilization of tree bark for filler in wood composite industry may promotes the diversity of biomass waste for value-added products as well as to support zero waste program. It leads to the important study of potentially utilization of tree bark of wood species as filler in wood composite manufacturing.

In the process of gluing, filler serves to fill the porous part of wood, such as vessel and other voids [7]. Generally, addition of filler into wood adhesive can improve gluing properties such as bonding strength, thermal stability, viscosity, and glue spreading. Moreover, adhesive penetration into wood surface and rheology could be controlled; while surface tension, formaldehyde emission, as well as raw material cost could reduced significantly [5-7, 12, 13, 16, 19, 21].

The high availability of bark and high phenolic content are an advantages in the utilization of bark as filler [19]. The previous studies of bark fillers in the manufacture of wood composite was mainly originated from softwood species $[7,18,19,21]$, which was probably due to the high abundance of softwood species in the temperate area. However, utilization of bark as filler from tropical hardwoods species is not investigated completely yet. Therefore, it is important to study the utilization of hardwood bark from tropical species as PF-filler.

Wood industry in Indonesia is facing the critical issue of decreasing wood supply. Woods have shifted from commercial species to lesser-known or lesser-used species. This is a challenge to create wood products from lesser-used species as an alternative or substitution of commercial wood by application the appropriate technology. This research used two lesser-used wood species, namely benuang (Octomeles sumatranal $\mathrm{BN}$ ) and duabanga (Duabanga moluccana/DB) to produce glued laminated timber (glulam). Both species are common species grown in Indonesia's natural forest and they are categorized as pioneer and fast-growing species [22]. This research aimed to analyze effect of tree barks as additional filler to PF on bonding strength of BN and DB glulams produced.

\section{Experimental}

\section{Sample and glue mixture preparation}

Log of BN and DB $120 \mathrm{~cm}$ length and $50 \mathrm{~cm}$ in diameter from East Kalimantan Province, Indonesia were used in this study. After debarking, the barks were converted to chips, while the logs were converted to wood samples. Chips were dried and then grinded by Willey mill. Bark powder of 60-80 mesh was used for the characterization, while the powder of 200 mesh for the additional filler. All powders were kept in sealed plastic bags before being used. 
Table 1 Technical information of PF from supplier

\begin{tabular}{lll}
\hline Parameter & Unit & Specification \\
\hline $\mathrm{pH}\left(\right.$ meter $\left./ 25^{\circ} \mathrm{C}\right)$ & - & 12.35 \\
Viscosity $\left(25^{\circ} \mathrm{C}\right)$ & Poise & 2.00 \\
Gelation time $\left(135^{\circ} \mathrm{C}\right)$ & Minute & $12^{\prime} 33^{\prime \prime}$ \\
Resin content $\left(135^{\circ} \mathrm{C}\right)$ & $\%$ & 43.1 \\
Specific gravity $\left(25^{\circ} \mathrm{C} / 4^{\circ} \mathrm{C}\right)$ & - & 1.2 \\
\hline
\end{tabular}

Table 2 Glue mixture composition

\begin{tabular}{llll}
\hline Test groups & Glue mixture composition & Parts by weight & Percentage \\
\hline A & PF & 10 & 100 \\
& Technical filler & 0 & 0 \\
B Bark filler & 0 & 0 \\
& PF & 10 & 83.33 \\
& Technical filler & 1.5 & 12.50 \\
& Bark filler & 0.5 & 4.17 \\
C & PF & 10 & 83.33 \\
& Technical filler & 1.25 & 10.42 \\
& Bark filler & 0.75 & 6.25 \\
D & PF & 10 & 83.33 \\
& Technical filler & 1 & 8.33 \\
& Bark filler & 1 & 8.33 \\
\hline
\end{tabular}

Wood sample of $1 \mathrm{~cm}$ by $5 \mathrm{~cm}$ by $20 \mathrm{~cm}$ then sanded with abrasive papers of P100 grits, and finally were air-dried to $\leq 12 \%$ of moisture content. All samples were then kept in room temperature of $(20 \pm 5){ }^{\circ} \mathrm{C}$ and relative humidity of $(70 \pm 5) \%$.

Liquid PF (PA-302; Supplier Pamolite Adhesive Industry, Jakarta, Indonesia) with technical specification in Table 1 was used. As a standard, PF was mixed with technical filler by ratio of $20 \mathrm{~g}$ of filler to $100 \mathrm{~g}$ of adhesive. The experiments were conducted for various combination of PF, technical filler, and bark fillers as presented in Table 2. Glue mixtures with different composition were applied for glulam manufacturing. Each glulam was made by using its bark as additional filler.

\section{Bark filler analysis}

Moisture content (MC), ash content, dissolved ethanol-benzena extractive content, and acidity $(\mathrm{pH})$ of bark were analyzed according to proper standard. Moisture content was determined according to TAPPI T 12 os-75 [23], ash content to ASTM D-1102 [24], extractive content to ASTM D-1107-96 [25], and $\mathrm{pH}$ was determined by $\mathrm{pH}$ meter.

Chemical components of BN and DB bark fillers were analyzed with pyrolysis Gas Chromatography-Mass Spectrometry (GC-MS). Viscosity of glue mixture was measured after $0,1,2$, and $3 \mathrm{~h}$ with viscometer UV-50. Glue mixtures were evaluated with a differential scanning calorimetry (DSC) at temperature $30{ }^{\circ} \mathrm{C}$ to $400{ }^{\circ} \mathrm{C}$ and a scan rate of $5{ }^{\circ} \mathrm{C} / \mathrm{min}$, with Argon UHP gas as medium. It was done to evaluate thermal properties of PF before and after mixing with bark filler. Chemical interaction between bark 
filler, technical filler and PF during curing process was analyzed using Fourier Transform Infrared (FTIR) Spectroscopy. Glue mixtures were placed in the oven at $130{ }^{\circ} \mathrm{C}$ for $1 \mathrm{~h}$ until reached a constant weight and then were ground into a fine powder. The powder was mixed with $\mathrm{KBr}$ crystals, with sample powder: $\mathrm{KBr}$ crystal ratio 1: 50. FTIR spectrum was recorded in the range of $400-4000 \mathrm{~cm}^{-1}$. The standard resolution of tool is $4 \mathrm{~cm}^{-1}$.

\section{Glulam manufacturing and characterization}

Glulam was manufactured by two plies lamina with five replications. Target dimension of glulam was $20 \mathrm{~cm}$ by $5 \mathrm{~cm}$ by $2 \mathrm{~cm}$ (length $\times$ width $\times$ thick). Approximately $250 \mathrm{~g}$ glue mixture per square meter was applied on double surfaces. Then, glulam was hotpressed with $20 \mathrm{kgf} / \mathrm{cm}^{2}$ pressure and $130{ }^{\circ} \mathrm{C}$ for $10 \mathrm{~min}$. All glulam were conditioned for 2 weeks before testing. Physical properties, bonding strength, wood failure, cold and boiling water delamination, and formaldehyde emission were determined to evaluate the effect of glue mixture on the glulam properties according to Japan Agricultural Standard (JAS) $1152[26]$.

\section{Statistical analysis}

Analysis of variance was conducted to evaluate effect of glue mixture composition on glulam properties. Duncan's test was used to determine the significant differences between the average values of the treatments.

\section{Results and discussion}

Basic properties i.e. $\mathrm{MC}, \mathrm{pH}$, ash content, and solubility in ethanol/benzene solution of each bark were tabulated in Table 3. Each species has different tree bark characteristic. Bark of $\mathrm{BN}$ has higher values of $\mathrm{pH}$ and ash content than bark of DB. Extractive content of DB bark was higher than that of BN bark. It was suggested that high extractive content contributes to the more acidity of DB bark. The acidity of wood is influenced by acetyl group of hemicellulose and extractive such as acetic acid, phenolic acid [27, 28]. The differences characteristic of barks may affect the suitability of bark as PF-filler.

Filler are generally used as additives in glue mixtures to increase viscosity and provide better gap filling properties and lower formulation costs [7,29]. Depending on these functions, the choice of filler is based on its effect on the adhesive's viscosity. Viscosity all glue mixtures are given in Fig. 1. Clearly seen, viscosity increased with increasing bark filler ratio. Ogban and Ogbobe [14] stated that the increased viscosity of glue mixtures is due to the high oil absorption ability of cellulosic filler. Figure 1 showed that initial viscosity of glue mixtures with BN bark filler was higher than glue mixtures with DB bark filler. It can be understood that $\mathrm{pH}$ value of $\mathrm{BN}$ bark is higher than the DB bark, since the

Table 3 Basic properties of BN and DB barks

\begin{tabular}{lllll}
\hline Bark & MC (\%) & pH & Ash content (\%) & $\begin{array}{l}\text { Dissolved ethanol- } \\
\text { benzene extractive } \\
\text { (\%) }\end{array}$ \\
\hline BN & 11.81 & 6.29 & 3.35 & 6.80 \\
DB & 11.80 & 4.24 & 1.86 & 11.18 \\
\hline
\end{tabular}



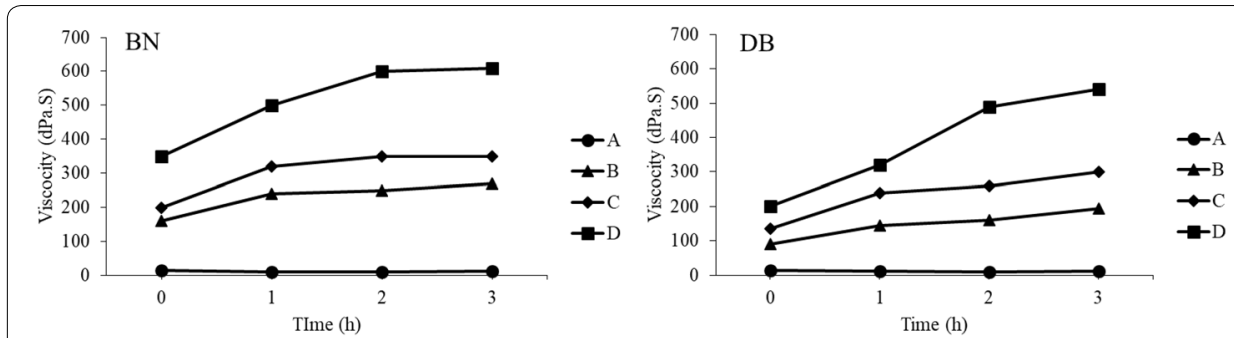

Fig. 1 Changes in viscosity of glue mixtures in time

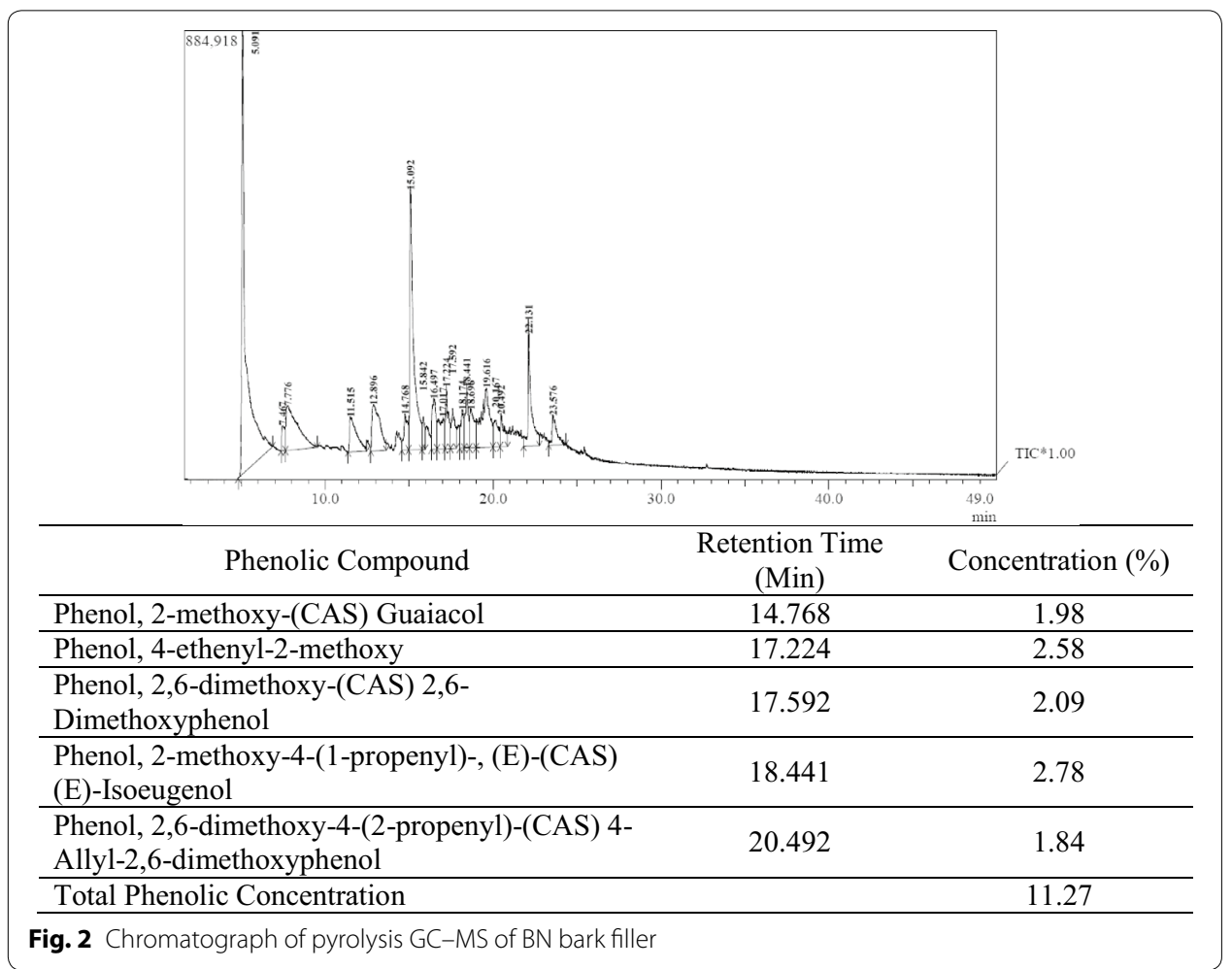

gel time of PF increase with increasing $\mathrm{pH}$ (alkaline condition) [4]. It also clearly seen that there was a dramatically increase viscosity's glue mixtures in time. It indicated the low storage life of these glue mixtures.

Pyrolisis GC-MS analysis showed phenolic compound and concentration of $\mathrm{BN}$ and DB barks was different, except for phenol, 2,6-dimethoxy-4-(2-propenyl)-(CAS) 4-allyl2,6-dimethoxyphenol (Figs. 2, 3). Even though it was similar, its concentration was different.

Total phenolic concentration of these two barks was also different. In case of BN bark, it was $11.27 \%$ and consisted of 5 compounds i.e. phenol, 2-methoxy-(CAS) guaiacol; phenol, 4-ethenyl-2-methoxy; phenol, 2,6-dimethoxy-(CAS) 2,6-dimethoxyphenol; phenol, 2-methoxy-4-(1-propenyl)-, (E)-(CAS) (E)-isoeugenol; and phenol, 2,6-dimethoxy-4-(2-propenyl)-(CAS) 4-allyl-2,6-dimethoxyphenol (Fig. 2). In case of DB bark, it was $5.17 \%$ and consisted of 4 compounds i.e. 4-vinyl-2-methoxy-phenol; 

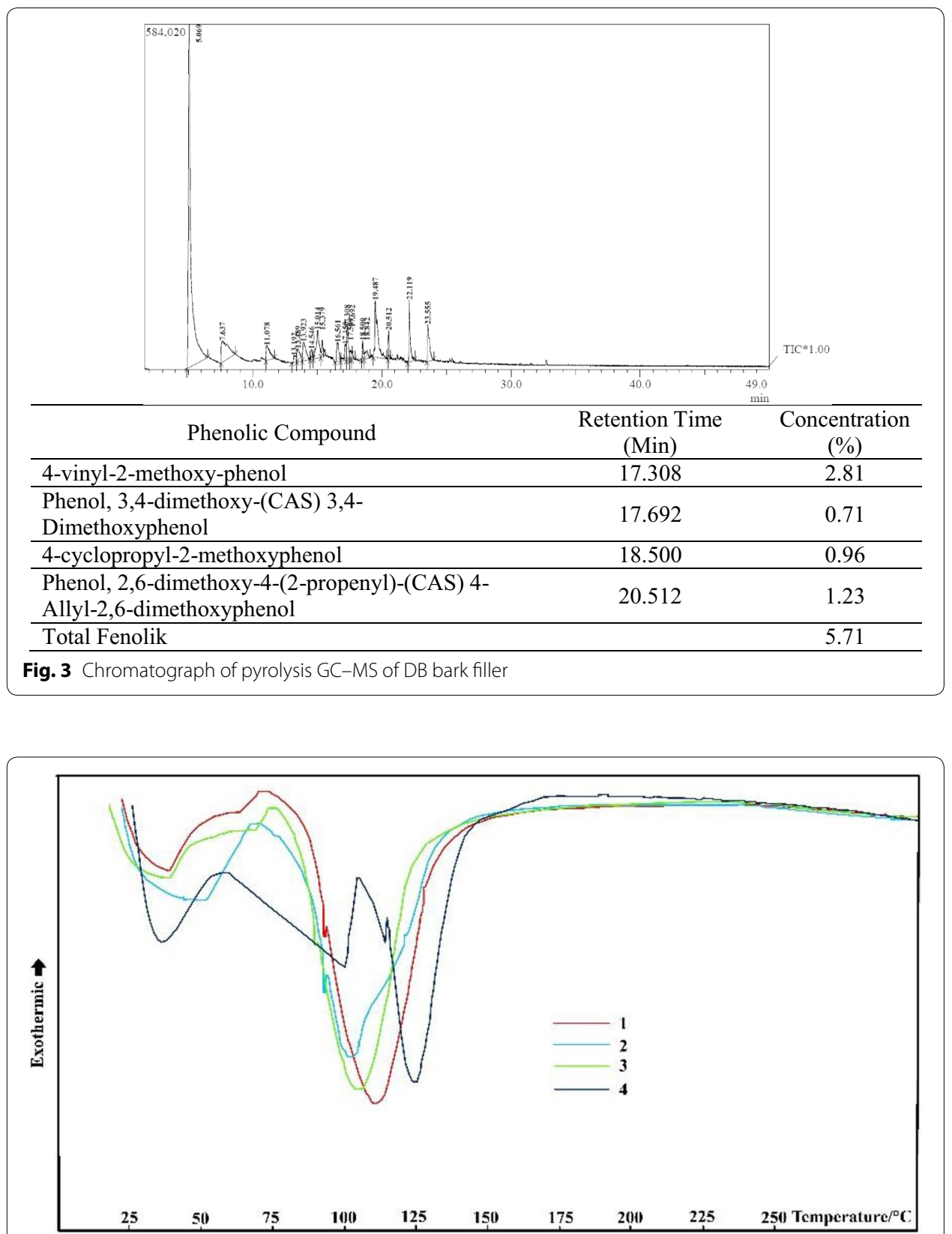

Fig. 4 DSC analysis of glue mixtures: (1) PF: technical filler: DB bark filler = 10: 1: 1, (2) PF: technical filler: BN bark filler $=10: 1: 1$, (3) PF: technical filler: bark filler $=10: 2: 0$, and (4) PF: technical filler: bark filler $=10: 0: 0$

phenol, 3,4-dimethoxy-(CAS) 3,4-dimethoxyphenol; 4-cyclopropyl-2-methoxyphenol; and phenol, 2,6-dimethoxy-4-(2-propenyl)-(CAS) 4-allyl-2,6-dimethoxyphenol. Different phenolic compounds and concentration of these two fillers affect their reactivity with formaldehyde. For instance, the higher total phenolic concentration of BN bark, the lower formaldehyde emission of its glulam, and vice versa (Fig. 2, Table 3).

The DSC results showed glue mixtures with additional technical and bark fillers exhibiting lower endotherms temperature than PF (Fig. 4). It indicates the glue mixtures cured faster than PF $[17,21]$. Figure 4 showed hydroxyl groups and moisture in technical and 
bark filler react with PF during curing process, and this process occurs at lower temperature [21]. Furthermore, Dukarska and Czarnecki [10] stated lower endothermic of glue mixtures was also caused by volatile substances in fillers. The DSC analysis also showed that glue mixture with additional BN bark cured in lower temperature than glue mixture with additional DB bark (Fig. 4). This is due to the differences of extractive substances' characteristic of these two barks [13]. Moreover, differences in the BN and DB bark fillers properties, such as acidity and total phenolic concentration impact the thermal properties. Benuang bark filler had lower acidity (higher $\mathrm{pH}$ value) and higher total phenolic concentration, so it gave lower thermal properties for the glue mixtures (Fig. 4).

FTIR spectra of cured glue mixtures with additional BN and DB bark fillers is presented in Figs. 5 and 6, respectively. The FTIR spectra of the bark sample showed a broad band at $3400 \mathrm{~cm}^{-1}$ (-OH stretching from intermolecular bonded), small peak at $2900 \mathrm{~cm}^{-1}$ (-C-H stretching) [18], a peak at $1600 \mathrm{~cm}^{-1}$ (aromatic skeletal vibrations plus $\mathrm{C}=\mathrm{O}$ stretching) [21], a weak to medium peak at $1300 \mathrm{~cm}^{-1}(\mathrm{O}-\mathrm{H}$ bending of phenol compound), peaks in the ranges of $1086-1033 \mathrm{~cm}^{-1}$ were associated with $\mathrm{C}-\mathrm{O}$ deformation of primary/secondary alcohols, $\mathrm{C}-\mathrm{O}$ stretch of cellulose, and $\mathrm{C}-\mathrm{H}$ deformation in guaicyl [21]. FTIR spectra of cured glue mixtures exhibited the same spectra of cured PF (control). Some differences peaks of glue mixtures, i.e. $1018 \mathrm{~cm}^{-1}$ and $1190 \mathrm{~cm}^{-1}$, were peaks from technical and bark filler with different intensity. It is due to the differences of technical and bark fillers ratio. Therefore, the FTIR results confirm that there were chemical reaction between the fillers and PF, and the fillers had merely blended physically with the PF.

Table 4 provides ANOVA of BN and DB woods glulam's characteristics. It clearly showed that glue mixture composition significantly affected $\mathrm{MC}$ of glulam, but did not affect the other parameters significantly. Moisture content of glulam was influenced by the MC of bark filler that used in glue mixtures (Table 1). Nevertheless, value of MC

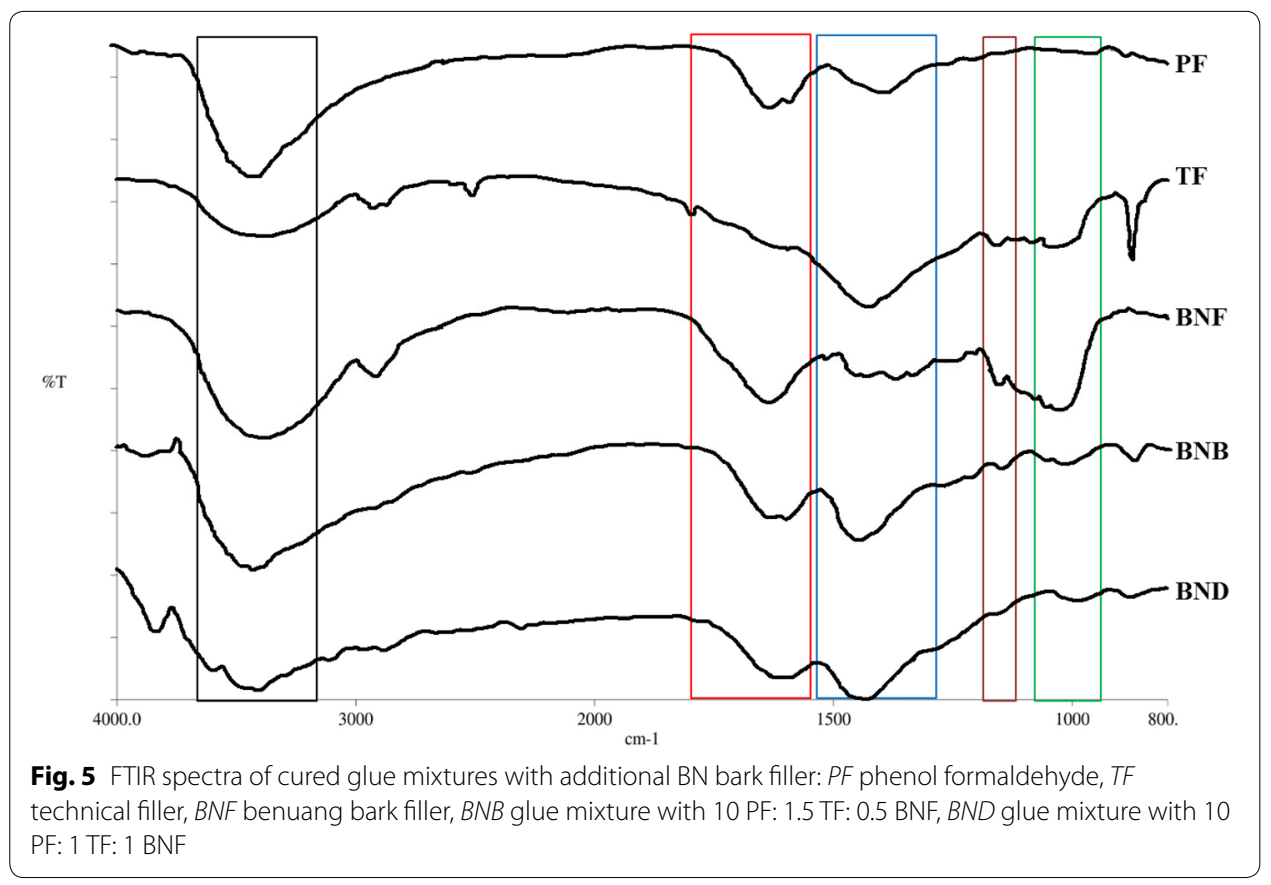




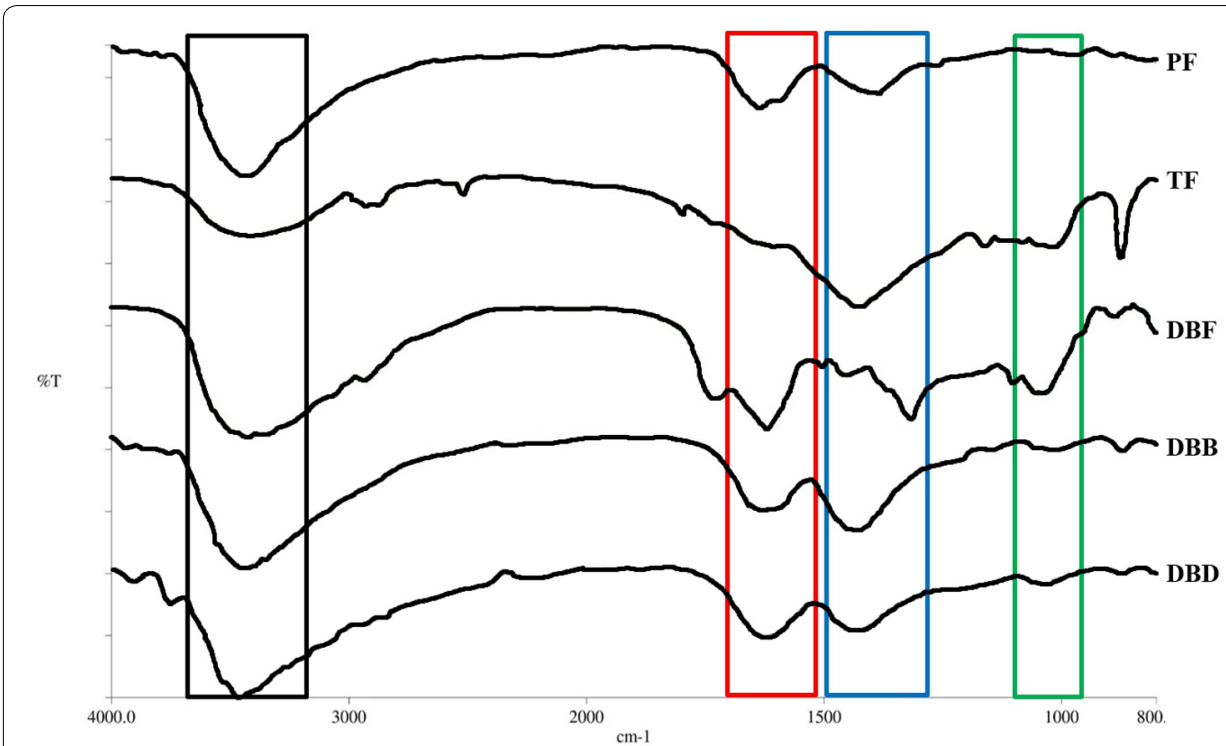

Fig. 6 FTIR spectra of cured glue mixtures with additional DB bark filler: $P F=$ phenol formaldehyde, TF technical filler, DBF duabanga bark filler, DBB glue mixture with 10 PF: 1.5 TF: 0.5 DBF, DBD glue mixture with 10 PF: 1 TF: 1 DBF

glulam met the required value by JAS 1152 i.e. $<15 \%$. Table 2 also clearly showed glue mixtures did not significantly affect the density. It means substituting technical and bark fillers up to 2 ratio parts weight of glue mixtures (16.67\%) did not significantly affect glue line weight, so it did not significantly affect the weight of glulam.

Effect of additional bark filler as well as the possibility of reducing the amount of adhesive in gluing process were investigated by analyzing cold and boiling water delamination as well as bonding strength. Result showed additional technical and bark fillers up to 2 ratio parts of glue mixture weight did not significantly affect delamination and bonding strength. Therefore, it is possible to reduce the amount of PF up to $16.67 \%$.

Bonding strength of DB glulam increased by increasing the bark filler ratio up to 1 ratio part glue mixture weight, while bonding strength of $\mathrm{BN}$ glulam increased only by increasing the bark filler ratio up to 0.5 ratio parts glue mixture weight. It is due to the viscosity's glue mixtures with additional BN bark filler is too high (Fig. 4). Viscosity's adhesive plays an important role in gluing process, since too high or too low viscosity gives a low bonding strength [8]. Too viscous adhesives are difficult to spread out and much of adhesives are remain on wood surface, hence decrease the efficiency contact area between wood and adhesives [14, 15]. It leads to weak the bonding strength. Nevertheless, overall, bonding strength each glue mixture composition of DB glulam met the required value by JAS 1152 , i.e. $>54 \mathrm{kgf} / \mathrm{cm}^{2}$, while $\mathrm{BN}$ glulam only on B glue mixture composition.

Wood failure of BN glulam for all glue mixture composition were $>90 \%$, while in DB glulam were $25-83 \%$. Wood failure of all BN glulam met required minimum value by JAS 1152, i.e. $>70 \%$, while A composition (control) of DB glulam did not. Wood failure of $\mathrm{BN}$ and $\mathrm{DB}$ glulams are shown in Fig. 7. It is clearly seen all failures of BN glulam occurred on wood, while failure of DB glulam with A composition occurred in the glue line. It indicated that bonding strength of BN glulam was higher than shear strength of 
Table 4 Analysis of variance of BN and DB woods glulam's characteristics with varied glue mixtures

\begin{tabular}{|c|c|c|c|c|c|c|c|}
\hline \multirow[t]{2}{*}{ Parameter } & \multirow{2}{*}{$\begin{array}{l}\text { Glue } \\
\text { Mixtures }\end{array}$} & \multicolumn{3}{|l|}{ BN } & \multicolumn{3}{|l|}{ DB } \\
\hline & & Mean & P-value & Remarks & Mean & P-value & Remarks \\
\hline \multirow[t]{4}{*}{ MC (\%) } & $A$ & $11.83(0.18)^{a}$ & \multirow[t]{4}{*}{0.00} & \multirow[t]{4}{*}{$* *$} & $11.00(0.14)^{\mathrm{a}}$ & \multirow[t]{4}{*}{0.00} & \multirow[t]{4}{*}{$* *$} \\
\hline & B & $11.72(0.19)^{\mathrm{a}}$ & & & $10.12(0.20)^{b}$ & & \\
\hline & C & $11.63(0.27)^{a}$ & & & $10.21(0.27)^{b}$ & & \\
\hline & $D$ & $11.22(0.29)^{b}$ & & & $10.17(0.28)^{b}$ & & \\
\hline \multirow[t]{4}{*}{$\rho\left(\mathrm{g} / \mathrm{cm}^{3}\right)$} & A & $0.40(0.02)$ & \multirow[t]{4}{*}{0.51} & \multirow[t]{4}{*}{ NS } & $0.48(0.02)$ & \multirow[t]{4}{*}{0.63} & \multirow[t]{4}{*}{ NS } \\
\hline & B & $0.41(0.04)$ & & & $0.47(0.04)$ & & \\
\hline & C & $0.43(0.02)$ & & & $0.50(0.02)$ & & \\
\hline & D & $0.41(0.03)$ & & & $0.49(0.03)$ & & \\
\hline \multirow{4}{*}{$\begin{array}{l}\text { Boiling water delamination } \\
\text { (\%) }\end{array}$} & A & $0.00(0.00)$ & \multirow[t]{4}{*}{-} & \multirow[t]{4}{*}{ NS } & $0.00(0.00)$ & \multirow[t]{4}{*}{-} & \multirow[t]{4}{*}{ NS } \\
\hline & B & $0.00(0.00)$ & & & $0.00(0.00)$ & & \\
\hline & C & $0.00(0.00)$ & & & $0.00(0.00)$ & & \\
\hline & D & $0.00(0.00)$ & & & $0.00(0.00)$ & & \\
\hline \multirow[t]{4}{*}{ Cold water delamination (\%) } & A & $0.00(0.00)$ & \multirow[t]{4}{*}{-} & \multirow[t]{4}{*}{ NS } & $0.00(0.00)$ & \multirow[t]{4}{*}{-} & \multirow[t]{4}{*}{ NS } \\
\hline & B & $0.00(0.00)$ & & & $0.00(0.00)$ & & \\
\hline & C & $0.00(0.00)$ & & & $0.00(0.00)$ & & \\
\hline & D & $0.00(0.00)$ & & & $0.00(0.00)$ & & \\
\hline \multirow[t]{4}{*}{ Bonding strength $\left(\mathrm{Kgf} / \mathrm{cm}^{2}\right)$} & A & $52.36(3.98)$ & \multirow[t]{4}{*}{0.18} & \multirow[t]{4}{*}{ NS } & $69.30(12.64)$ & \multirow[t]{4}{*}{0.44} & \multirow[t]{4}{*}{ NS } \\
\hline & B & $54.19(5.32)$ & & & $70.04(8.77)$ & & \\
\hline & C & $50.40(8.85)$ & & & $75.89(2.12)$ & & \\
\hline & D & $44.83(7.42)$ & & & $77.18(10.03)$ & & \\
\hline \multirow[t]{4}{*}{ Wood failure (\%) } & A & $94.00(2.24)$ & \multirow[t]{4}{*}{0.03} & \multirow[t]{4}{*}{ NS } & $32.00(21.39)$ & 0.00 & $* *$ \\
\hline & B & $98.00(2.74)$ & & & $77.00(13.96)$ & & \\
\hline & C & $100.00(0.00)$ & & & $76.00(18.17)$ & & \\
\hline & D & $97.00(4.47)$ & & & 87.00 (12.04) & & \\
\hline
\end{tabular}

Numbers in the parentheses are standard deviation values

$a, b$ significantly different between treatments (glue formulae)

** Significantly different (P-value $\leq 0.01$ )

NS not significantly different

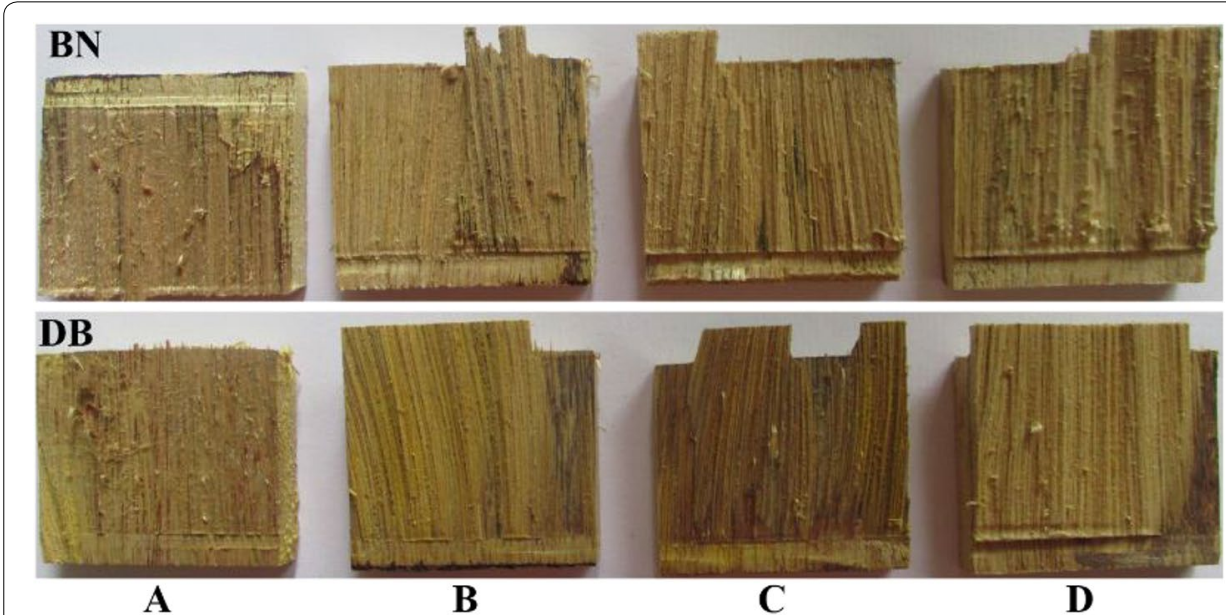

Fig. 7 Wood failure of BN and DB glulams with varied glue mixtures composition 
Table 5 Formaldehyde emission of BN and DB glulams with varied glue mixtures

\begin{tabular}{llllll}
\hline Glue mixtures & BN & & & DB \\
\cline { 2 - 2 } \cline { 5 - 6 } & $\begin{array}{l}\text { Formaldehyde } \\
\text { emission }(\mathbf{m g} / \mathbf{l})\end{array}$ & Performance class & & $\begin{array}{l}\text { Formaldehyde } \\
\text { emission }(\mathbf{m g} / \mathbf{l})\end{array}$ & $\begin{array}{l}\text { Performance } \\
\text { class }\end{array}$ \\
\hline $\mathrm{A}$ & 0.104 & $\mathrm{~F}^{* * * *}$ & 0.094 & $\mathrm{~F}^{* * * *}$ \\
$\mathrm{~B}$ & 0.082 & $\mathrm{~F}^{* * * *}$ & 0.245 & $\mathrm{~F}^{* * * *}$ \\
$\mathrm{C}$ & 0.133 & $\mathrm{~F}^{* * * *}$ & 0.315 & $\mathrm{~F}^{* * * *}$ \\
$\mathrm{D}$ & 0.059 & $\mathrm{~F}^{* * * *}$ & 0.255 & $\mathrm{~F}^{* * * *}$ \\
\hline
\end{tabular}

BN wood. Meanwhile, bonding strength of DB glulam with A composition was lower than shear strength of DB wood. Thus, it can be concluded that additional bark filler in glue mixtures increases the wood adhesion. This result is same with result from Winkler et al. [30], which stated additional filler did not impact the wood bonding strength.

Formaldehyde emission from BN and DB glulams with different glue mixture composition is shown in Table 5. Formaldehyde emission occurs due to formaldehyde gases do not react perfectly during gluing process hence it releases into the air. As can be seen in Table 5, additional bark filler in B and D composition in BN glulam reduced formaldehyde emission compared to the control, while additional bark filler in DB glulam had no measurably clear effect. Previous study also shown the same result. Aydin et al. [19] proved that additional chestnut and fir bark fillers positively affected the decreased formaldehyde emission, while walnut and spruce bark fillers had no measurably effect. The reason for the decreased formaldehyde emission with increasing filler ratio was the high phenolic content of bark, even though the reactivity for formaldehyde varied depending on the phenolic compound [31]. It is in line with GC-MS analysis result. Phenolic compound of BN and DB barks were different (Fig. 2 and 3). Moreover, phenolic concentration of these two barks were also different, where total phenolic concentration of BN bark was higher than DB. Hence, BN bark filler had a positive effect on reducing formaldehyde emission compared to DB bark filler. Nevertheless, formaldehyde emission of all glulam was classified into $\mathrm{F}^{* * * * *}$, that was the lowest emission and the best categorize according to JAS 1152.

\section{Conclusions}

Benuang and duabanga barks are potential to be used as filler for PF for glulam manufacturing. Bonding strength was influenced by wood species and glue mixture composition. The lowest ratio of tree bark filler is the best for $\mathrm{BN}$ glulam, while the highest ratio of bark filler is the best for DB glulam. Additional technical and bark fillers up to 2 ratio parts weight of glue mixture did not reduce the performance of glulam. High bonding strength and wood failure, as well as low delamination of glulam proved that bark filler increased the quality of wood adhesion. The differences type of phenolic compound and total phenolic concentration of $\mathrm{BN}$ and $\mathrm{DB}$ barks affect the reactivity of fillers for formaldehyde emission. 
scanning spectrometry; FTIR: Fourier Transform Infrared; GC-MS: Gas chromatography-mass spectrometry; Glulam: Glued laminated timber; JAS: Japan Agricultural Standard; KBr: Potassium bromide; MC: Moisture content; PF: Phenol formaldehyde; PF-Filler: Filler for phenol formaldehyde; pH: Acidity.

\section{Acknowledgements}

The authors would like to thank to Ministry of Research, Technology, and Higher Education of Indonesia for funding this research under PMDSU grant.

\section{Authors' contributions}

SDM participated in the experiments and writing of the manuscript; IW (corresponding author) was responsible for completion of the article and guidance of the experimental work of this paper; JS and DSN participated in experimental design and coordination, helping to prepare the manuscript. All authors read and approved the final manuscript.

\section{Funding}

This research was funded by Ministry of Research, Technology, and Higher Education of Indonesia.

\section{Availability of data and materials}

All relevant data is presented in the manuscript and additional information can be made available on request if necessary.

\section{Competing interests}

The authors declare that they have no competing interests.

\section{Author details}

${ }^{1}$ Forest Products Science and Technology Study Program, IPB University, Bogor 16680, Indonesia. ${ }^{2}$ Department of Forest Product, Faculty of Forestry, IPB University, Bogor 16680, Indonesia.

Received: 23 January 2020 Accepted: 5 March 2020

Published online: 16 March 2020

\section{References}

1. Frihart CR. Introduction to special issue: wood adhesives: past, present, and future. Forest Prod J. 2015;65(1-2):4-8.

2. Pizzi A, Mittal KL. Handbook of adhesive technology. 2nd ed. New York: Taylor \& Francis Group, LLC; 2003.

3. Mölleken RE, Trianoski R, Neto SC, Pereira CR, Iwakiri S, Azevedo C. Evaluation of pressing time in the production of edge glued panel with polyurethane derived from castor oil. Appl Adhes Sci. 2016;4:9. https://doi.org/10.1186/ s40563-016-0066-4.

4. Pereira CR, Mölleken RE, de Souza FH, Capellari GS, Neto SC, Azevedo C. Evaluation of MDF bonding with polyurethane of castor oil. Appl Adhes Sci. 2016;4:13. https://doi.org/10.1186/s40563-016-0070-8.

5. Yang X, Frazier CE. Influence of organic fillers on rheology behavior phenol-formaldehyde adhesives. Int J Adhes Adhes. 2016;66:93-8.

6. Yang X, Frazier CE. Influence of organic fillers on surface tension of phenol-formaldehyde adhesives. Int J Adhes Adhes. 2016;66:160-6

7. Ruziak I, Igaz R, Krist'ak L, Reh R, Mitterpach J, Ockajova A, Kucerka M. Influence of urea-formaldehyde adhesive modification with beech bark on chosen properties of plywood. BioResources. 2017;12(2):3250-64.

8. Mohsen RM. Effect of calcium carbonate filler on polyvinyl acetate emulsion as wood adhesive. Pigm Resin Technol. 1992;21(10):10-1.

9. Juqing C, Zhiqiang W, Bin N, Shuguang H, Xiaoyan Z, Xiaoning L. Effect of molar ratio and fillers on creep behavior of phenol-formaldehyde and melamine-urea-formaldehyde thermosetting adhesives. Cell Chem Tech. 2012:46(7-8):463-6.

10. Dukarska D, Czarnecki R. Fumed silica as a filler for MUPF resin in the process of manufacturing water-resistant plywood. Eur J Wood Prod. 2015. https://doi.org/10.1007/s00107-015-0955-4.

11. Özkaya K, Ayrilmis N, Özdemir S. Potential use of waste marble powder as adhesive filler in the manuafacture of laminated veneer lumber. BioResources. 2015;10(1):1686-95.

12. Li X, Luo J, Li J, Gao Q. Effects of diatomite inorganic fillers on the properties of a melamine-urea-formaldehyde resin J Appl Polym Sci. 2016;44095:1-8.

13. Oh Y-S, Sellers TJ. Korean filler raw materials for plywood adhesives. Forest Prod J. 1999:49(3):61-4

14. Ogban IU, Ogbobe O. The effect of agro-wastes and crustacean fillers on poly (vinyl-acetate) emulsion wood adhesives. Int J Polym Mater Po. 2008:57:266-74.

15. Bono A, Ismail NM, Anisuzzaman SM, Saalah S, Chiw HK. The performance of melamine-urea-formaldehyde resin with palm kernel as filler. Adv Mater Res. 2011;233-235:3-10. https://doi.org/10.4028/www.scientific.net/ AMR.233-235.3.

16. Ong HR, Khan MR, Yousuf A, Jeyaratnam N, Prasad DMR. Effect of waste rubber powder as filler for plywood application. Polish J Chem Technol. 2015;17(1):41-7.

17. Sutrisno Alamsyah EM, Sulistyawati E, Suheri A. The potential use of wood waste ash nanofiller for improvement of laminated veneer lumber production made from Jabon (Anthocephalus cadamba). J Indian Acad Wood Sci. 2018. https://doi.org/10.1007/s13196-018-0217-2.

18. Eberhardt TL, Reed KG. Strategies for improving the performance of plywood adhesive mix fillers from Southern Yellow Pine bark. Forest Prod J. 2006;56(10):64-8.

19. Aydin I, Demirkir C, Colak S, Colakogla G. Utilization of bark flours as additive in plywood manufacturing. Eur J Wood Prod. 2016. https://doi.org/10.1007/s00107-016-1096-0. 
20. Blanchet P, Cloutier A, Riedl B. Particleboard made from hammer milled black spruce bark residues. Wood Sci and Technol. 2000;34:11-9.

21. Chen $\mathrm{H}$, Yan N. Application of Western red cedar (Thuja plicatal) tree bark as a functional filler in pMDI wood adhesives. Ind Crop Prod. 2018;113:1-9.

22. Ogata K, Fujii T, Abe H, Baas P. Identification of the timbers of Southeast Asia and the Western Pacific. Shiga-Ken: Kaiseisha Press; 2008.

23. Technical Association of Pulp and Paper Industry. T 12 os-75 preparation of wood for chemical analysis (including procedures for removal of extractive and determination of moisture content. Atlanta: TAPPI; 1978.

24. American Society for Testing and Material. ASTM D1 102-84 standard test methods for ash in wood. West Conshohocken: ASTM; 2001.

25. American Society for Testing and Material. ASTM D1107-96 standard test methods for ethanol-toluene solubility of wood. West Conshohocken: ASTM; 2007.

26. Japan Agricultural Standard. Japanese agricultural standard for glued laminated timber No. 1152. Ministry of Agriculture, Forestry and Fisheries, Tokyo; 2007.

27. Fengel D, Wegener G. Wood-chemistry, ultrastructure, reactions. New York: Walter de Gruyter; 1984.

28. Rowell RM. The chemistry of solid wood. 1st ed. Washington: American Chemical Society; 1984

29. Petrie EM. Handbook of adhesive and sealants. New York: McGraw-Hill; 2000.

30. Winkle C, Schwarz Konnerth J. Effect of thermal postcuring on the micro- and macromechanical properties of polyurethane for wood bonding. Appl Adhes Sci. 2018;6:5. https://doi.org/10.1186/s40563-018-0106-3.

31. Hoong YB, Paridah MdT, Loh YF, Jalaluddin H, Chuah LA. A new source of natural adhesive: acacia mangium bark extracts co-polymerized with phenol-formaldehyde (PF) for bonding Mempisang (Annonaceae spp.) veneers. Int J Adhes Adhes. 2011;31:164-7.

\section{Publisher's Note}

Springer Nature remains neutral with regard to jurisdictional claims in published maps and institutional affiliations.

\section{Submit your manuscript to a SpringerOpen ${ }^{\odot}$ journal and benefit from:}

- Convenient online submission

Rigorous peer review

- Open access: articles freely available online

- High visibility within the field

Retaining the copyright to your article

Submit your next manuscript at $\mathbf{s p r i n g e r o p e n . c o m ~}$ 